预。也就是使自然產生有定向的變異。

山於米邱林的工作是有思想领算的, 是基於

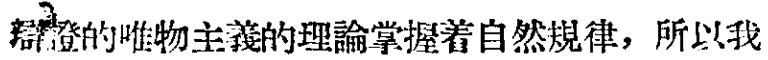
們肯定他的工作方法是科學的方法。他的成功, 也 亚不是僅僅“不灰心”和 ‘在工作上努力’ 而已!

李敉授忽略了米邱林在工作中思想方啮的改 䙪, 僅僅說是 新認識' 已經是不够的。簡單的詒是 “多年的觀察和筫驗的結果推論出來的”, 容易使 人就解第米邱林是沿用了形式䢰輯的一切演釋的 ‘推論”。就會流於使創造的偉大科學家掂俗化。

\section{三、米邱林“對售选傅學造詣很深’}

李敉授在結論上肯定的說: ‘米邱林對於舊遗 㒄學造涽很深, 這然一句使米邱林不能承認的話。 因第這在科學的原则上是含有淆减性的, 很容易 引人入迷, 很容易使人認篇新鹤遺傅學之間亚沒

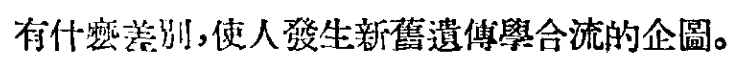

可是在科學的原则上，新舊遗傅學是出發於 雨倜絕然相反的範疇, 而不可能合流的。更不是嗬 通了“舊的”, 才能搞通 '新的” 的。相反的, 精通舊. 遗傳學的,如果不在思想上改變,幾乎不可能正碓 的齿理解米邱林學說。

從米邱林選集, 我們是可以知道米邱林一生

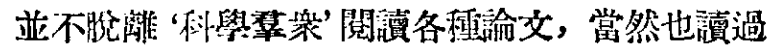
‘孟德雨以及莫爾于派的諭著'。可是不僅浑有把 這些 “諭著”常作 '科學”去造就, 而且不斷的用實 際工作來反龁這些 “害人的東西' (米邱林說的)。

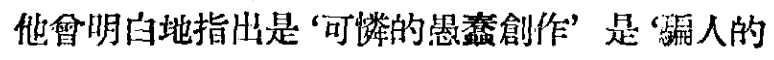
法则”, 是 ‘遠背自然的真理”一這選集中可以找到
好些這類此言F, 如對韓生(Hansen)数授的報告,

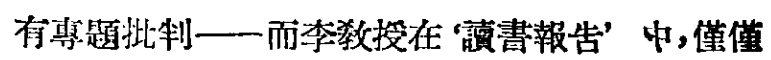
提到 ‘他對孟德爾律的普遍性不接受”一句。反而 說米邱林数售遗傅學造涽很深,這是不正確的。

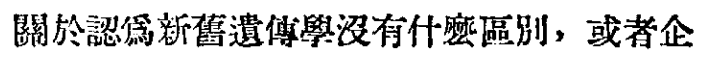
圖合流的這種不正確的看法。由斯托拉托夫院長

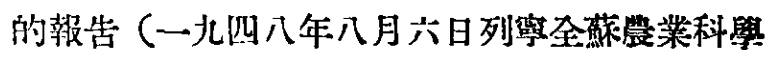

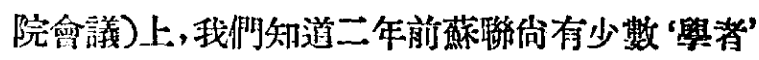
一例如莫爾于派的羅馬雪夫 (Romashov) 會公閉發表這種歪曲諭調。羅馬雪夫甚至领說: “在米邱林的一生事業中, 找不期任何資料是與近 代遺傅學或染色體遺傅學的基本原则相迋背的。”

於此, 是不是指的米邱林“對鹤遺傅學造浩很 深”的這話, 是否指米邱林舉說是必須建立在鹤遺 傅學的基礎上呢?

但是,我們確賽認定只有勇敢的,堅决的否定 莫爾干派的 “遗傅理諭”, 才能够正確的搞通米邱 林學說。否则, 只有走向調和派一中間路線了。

李教授在結諭指洲: “把 ‘中國米邱林” 㵱號 在口頭上或文宇上隨便肋來棌維人, 這也足不對

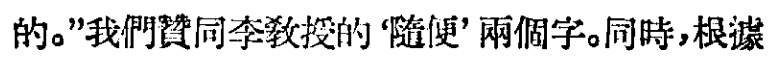
米邱林學說的基本精神, 凡是在有意識或焦意識 中, 掌握了生物發鼠規律, 增加或提高生產, 堵進 人民的幸福的工作者, 不諭是學者, 或者是老鄉, 我們是可以僄稃瓷 ‘中國米邱林”。

最後, 我所提出的意見, 也不一定正碓和週 全,除求呚於李呚授外，還希各方讀者予以指正。 共篇新中國生物科學的學替而努力。

\title{
我對於 ‘米邱林工作介紹”一文的檢討
}

\section{李 繼 侗}

在憸討之前, 我要把我選擇遺個題目的動機 申述一下。賞我在去年看了李森科一九四八年在 列察全蘇農業科學院會議的演講詞以後, 我就生 了一稴唂望, 想瞭解米邱林的工作。他的工作方 一法, 和他的工作精神。藉此可以得到啓發和指導, 以便在教學有餘力的時候, 做一兩個小規模比較 接近實際的研究。這是我頦米邱林選集的主要目 的。同時我們的學生聽了斯托列夫院粫和努日金
鈤士的演講後, 也迫切的想要知道米邱林的工作 和工作方法。因此我就作了一次大膯的嘗試, 選 擇這個題目。意照是對兩位覃家的演講, 做點註解 工作, 絕不敢說對於米邱林做一個全面的介紹。

陳先生對我演講的意見是分成三段，下面逐 段的回答。

\section{一、䍌於米邱林選集誨搌的不恰當}

這段批訣的主要點是不全面, 這點我誠心的 
接受。我所要检討的就是這倜演請亚不是要對於

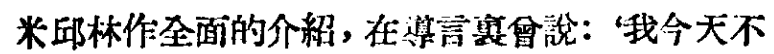
作學理上的討諭, 只把米邱林一生重要的工作, 特 别是他的工作方法作一倜简單的介紹'。可是在行 文上犯了丽倜錯誤, 以至引起了批部。第一储錯誤

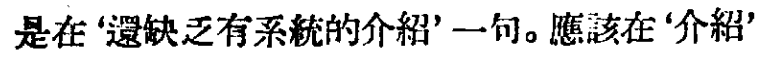
二字前加上 ‘中文”二字。第二個錯誤是在 '.......是

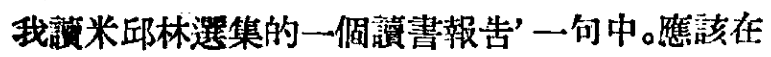

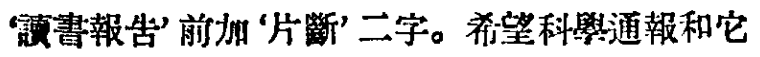
的管者谁許我改正。

逼一段中陳先生遻覺得我不應該在演講中把 米邱林電影和米邱林選集蓝提, 資我不品薡。這一 點似乎可以商討的。我個人認瓷現在在北京上演 的米邱林電影和巴甫洛夫電影是落聯普及科學的 工具，人民大衆科學知濖的源泉。十二蕰分的菲 琵，絕對不是低級的。

\section{二、没有從思想上去瞭解米邱林工作}

遥個批評我完全接受。我遚在想想改造和學 習時期, 而㯰個問題.我還在摸索之中。

至於我演講第六段中“米邱林的新認識是根 掉多年的觀察和望驗結果推諭计來的”一句中“推 諭二字, 我虚心的接受批評, 把造一句改成·米邱 林新認識是綜合多年 觀察和 實驗的結 果而得來 的。'

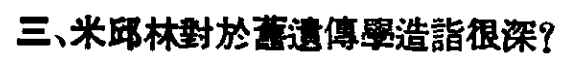

在这一段中陳先生提陁四個批評。第一點是 在結諭上 ‘ 凡是演過米邱林選集的人沒有不感覺 到他對於稙物生理學, 對於鹤遺傅學造涽很深’一

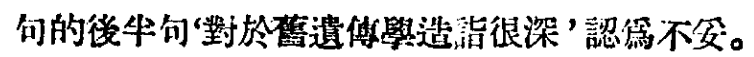
賞初講的時候, 我自己也覺得不安賞, 本想用“瞙

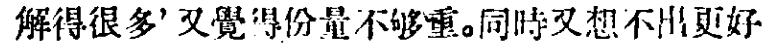

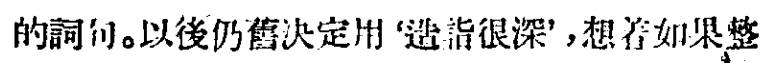

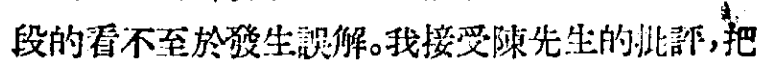
“造站很深 '改成” 瞭解得很多'

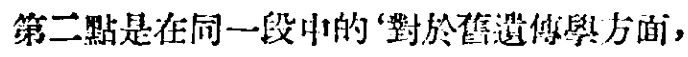

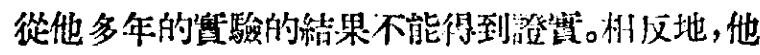

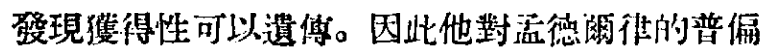
性不接受。他叫它踠豆律'。四分中第三句。陳先生 是把第三们孤立起來批評了。

第三點陳先生指示我說“是不是㙐通“嚄的”才

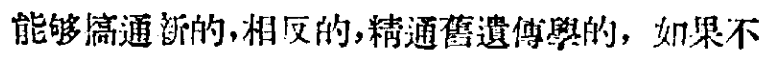
在思想上改變, 幾乎不可能正礁的去理解米邱林 燢祾”。這们活我完全同意。可是我個人有一點經

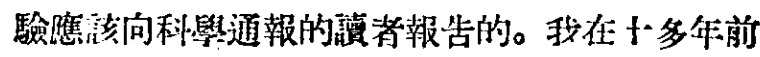

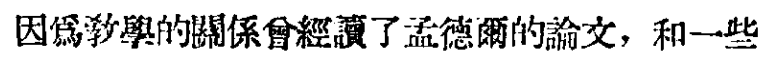

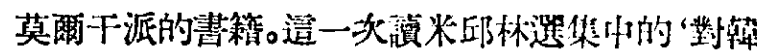

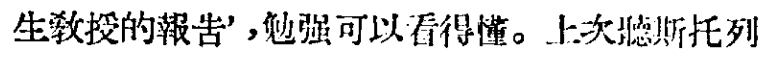

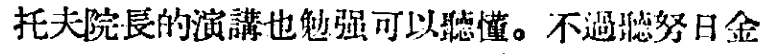
博土的演講,他對於萑遺傅學的批判非学深入,有 一兩講我就不可能完全澺得懂。清萿生物系有浇 位年青的同事,也有闹檬的經䲆。

第四點陳先生涗 “凡是在有意識或考與意裁

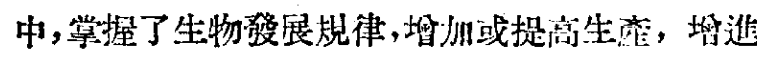
人民的㐋福工作者，不論是學者，或省老鄉，我們

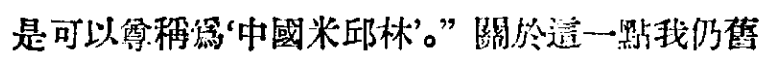
不能同意。因媱李森科的偉大是我們所公認的,可 是亞歷克山達特洛夫在他所落的李森科傅中只程 李森科第米邱林學說的纕承人。其筡像道爾辛科 院士,斯托列托夫院長,努日金情士等自称或者互 称也只是米邱林路綫的工作者。

\section{蘇聯各地選舉二届全蘇和大代表 著名科學家八十四名亦當選}

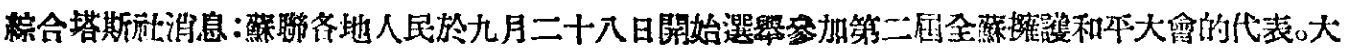
要已定於十月1六日在莫斯科舉行。

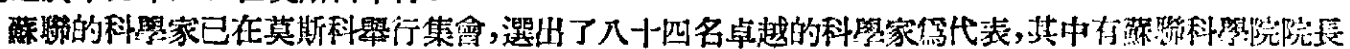

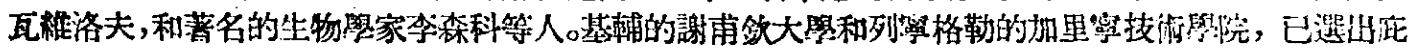

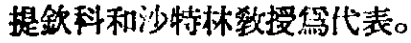

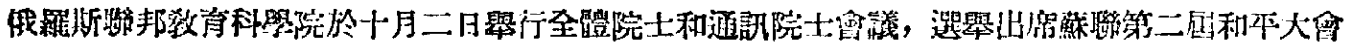

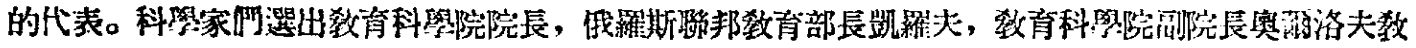

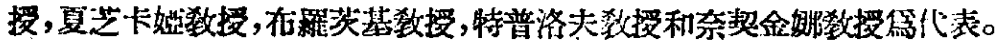

(新范核上稿) 